\title{
Concept of jihad and its nature in Islam
}

\author{
Abdulmajeed Hassan Bello, ph.D
}

\begin{abstract}
This paper argues that the word Jihad is commonly translated into English as 'the holy war' and for a long while now the word has been interpreted so that it has become synonymous with a mania of religion. But the word Jihad does not mean 'holy war.' The concept of 'holy war' does not occur in the term Jihäd, which in

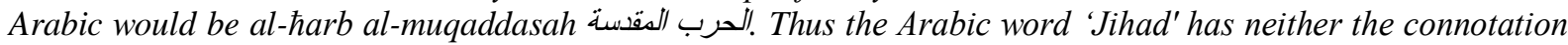
of "holy" nor that of "war". Islam simply put an end to the wars of aggression and permitted only defensive war under certain conditions after all effort to keep the peace has failed and enemy impose was on the Muslim State. Such defensive war is permitted in order to restore the condition of peace, but not to disturb the peace. Islam does not advocate "the law of the jungle and does not give Muslims any right to take life of others. Jihad is not terrorism; terrorism is under no circumstances permissible in Islam. But It is apparent that the understanding of Jihad as a concept is dismally blurred and employed by the extremists, and the only way to dispel the false notions of Jihad put forth by the extremists, who are massively funded by external sources, is an equally strong effort put forth by Muslim governments in re-education of their populations, in particular the youth, with a correct understanding of this term.
\end{abstract}

Key words: al-harb al-muqaddasah, Jihad, terrorism, and holy war.

\section{Introduction}

A very great misconception prevails with regard to the duty of jihad in Islam, by assuming that the word jihad is supposed to synonymous with war; and even the greatest research scholars of Europe have not taken the pains to consult any dictionary of the Arabic language, or refer to the Qur'an, to find out the true meaning of the word. $\left({ }^{1}\right)$ Today there are many individuals who study Islam from a superficial point of view and emerge with their own ideas and imaginary interpretations which often diverge greatly from the established legislation in the area of study. Because of such studies lacking a true basis in Islamic jurisprudence, many nonMuslims are given a bad understanding about Islam. So in this paper we will return to the original source texts bringing up the issue of Jihad in order to explain its various different facets and clarify its understanding once and for all. The word Jihad is commonly translated into English as 'the holy war' and for a long while now the word has been interpreted so that it has become synonymous with a mania of religion. $\left({ }^{2}\right)$ But the word Jihad does not mean 'holy war.' The concept of 'holy war' does not occur in the term Jihād, which in Arabic would be al-ћarb al-muqaddasah الحرب المقدسة. Throughout the entire Qur'ān one cannot find a term that expresses the meaning "holy war." ${ }^{3}$ ) Jihad means effort or endeavors against man's own self. Jihad is to work hard to do right things. Islam ask his followers to recognize their duty towards themselves, and that duty is Jihad, striving for good against evil, beginning with the conquest of a man's own lusts. His training for Jihad is not only military training; it is the whole structure of Islamic discipline. Without the wider human aim there can be no Jihad. In the religious sense, it probably applies to the whole effort of the Muslim to assert and establish the sovereignty of God in men's mind, by performing his religious duty as laid down in the Quran, an effort, which should last through all his life. It should govern every action of his life, or he is no true Muslim. $\left({ }^{4}\right)$ Thus the Arabic word 'Jihad' has neither the connotation of "holy" nor that of "war". The translation of the word 'Jihad' with "holy war" is arbitrary, tendentious and absurd. $\left(^{5}\right)$ The word simply applies to any activity or job which is accomplished with great effort and which calls for striving hard. Maximum effort applied to a task is 'Jihad'. Great sacrifice of one's time, of one's personal honour for a noble cause is 'Jihad'. ( ${ }^{6}$ ) Sheikh Nasir Ahmad states:

The proclamation and preaching of truth under circumstances involving great risk to one's life is 'Jihad'. To rise against a tyrant in defence of the victims of oppression is 'Jihad'. The struggle against one's weakness, one's

\footnotetext{
${ }^{1}$ Ali, " The Religion," 450.

${ }^{2}$ S. Abul A'la Maududi: Jihad in Islam, Damascus: The Holy Koran Publishing House, 1977, 1.

${ }^{3}$ http://islamicsupremecouncil.org/understandin-islam. Shaykh Muhammad Hashim Kabbani, Insurgents $(15 / 10 / 2012)$

${ }^{4} \mathrm{http}: / /$ islamicsupremecouncil.org/understandin-islam.

${ }^{5}$ Sheikh Nasir Ahmad, "the Militant Islam", the Review of Religions, Lxxxi, no. 3, (1986): 18.

${ }^{6}$ Ahmad, 18.
} 
egoism, against the moral decay of the society, against oppression and wrong, against an enemy who attacks one's country, against compulsion in matters of and against the persecution of the innocent-all comes under the category of 'Jihad" ( ${ }^{7}$ )

Therefore, Jihad is a duty in Islam, but this duty may be summarized as the fight for good against evil in every connection and in every field, beginning with a man's own heart and mind. Thus today it can be used to describe the personal struggle to keep the fast of Ramadan, to lead a good life, to fulfill family responsibilities, popularly it is used to describe the struggle for educational or social reform-to establish good schools, to clean up a neighborhood, to fight drugs, or work for social justice. $\left({ }^{8}\right)$ Prophet Muhammad (peace be upon him) said: "The greatest Jihad is that against a man's own lust;" ( $\left.{ }^{9}\right)$ Suyuti said: al-Khatib al-Baghdadi relates in his "History" on the authority of Jabir:

The Prophet came back from one of his campaigns saying: You have come forth in the best way of coming forth: you have come from the smaller jihad to the geater jihad." They said: "And what is the greater jihad?" He replied: "The striving mujahadat (مُجَهَهَة) of Allah's servants against their idle desires. $\left({ }^{10}\right)$

This means that the best way of recommending the belief in Allah's universal sovereignty and extending the new realm of peace and brotherhood is by the example of righteous conduct. The term "Al-Jihad-ul-Akbar "The greatest 'Jihad', is also applied by the Holy prophet (peace be upon him) to the effort of the student to become learned and the effort of the learned to spread knowledge."The superiority of the learned man over a mere worshiper is like my superiority over the least of you." $\left({ }^{11}\right)$

Jihad thus means serious and sincere struggle on the personal as well as on the social level. It is a struggle to do well and to remove injustice, oppression and evil from the society. This struggle should be spiritual as well as social, economic and political. In the Quran this word is used in its different forms 33 times. It often comes with other Quranic concepts such as faith, repentance, righteous deeds and migration. $\left({ }^{12}\right)$ It is therefore incorrect to limit the meaning of the term to warfare of the fanatical religious kind that brought blemish, shame and worldwide condemnation to the Muslim world and the religion of Islam itself. Allah says: "and fight them until there is no persercution, and religion is professed only for Allah. But if they desist, then remember that no hostility is allowed except against the wrongdoers." $\left({ }^{13}\right)$ This is to say that Jihad is not supposed to include aggressive warfare, but this tactic has been invoked by early extremists like Khaijites, by rulers to justify their wars of conquest and expansion, and by contemporary extremists such as Osama bin Laden and his Jihad against America as well as Jihad organization in Lebanon, the Persian Gulf, and Indonesia. $\left({ }^{14}\right)$ Today there are many individuals who study Islam from a superficial point of view and emerge with their own ideas and imaginary interpretations which often diverge greatly from the established legislation in the area of study. Because of such studies lacking a true basis in Islamic jurisprudence, many non-Muslims are given a bad understanding about Islam. So we are of the opinion that the best is to return to the original source texts bringing up the issue of Jihad in order to explain its various different facets and clarify its understanding once and for all.

\section{Objective of Jihad}

As far as war is concerned, Islam does not permit a war of aggression for purpose of expansion. To understand the term 'purposes of expansion' we must go back to the condition of obtaining at the time of early Islam when such wars of aggression were order of the day. Islam simply put an end to the wars of aggression and permitted only defensive war under certain conditions after all effort to keep the peace has failed and enemy impose was on the Muslim State. Such defensive war is permitted in order to restore the condition of peace, but not to disturb the peace. $\left({ }^{15}\right)$ This would be clear if we cast a glance at the wars in which early Muslims were involved involuntarily.

\footnotetext{
${ }^{7}$ Ahmad, 18.

${ }^{8}$ Esposito, 223.

${ }^{9}$ Ibn Hajar al- Asqalani said in Tasdid al-qaws: "This saying is widespread and it is a saying by Ibrahim ibn Ablah according to Nisa'i in al-Kuna.

${ }^{10}$ The Prophet said in the Farewell Pilgrimage: "... The mujahid is he who makes jihad against himself for the sake of obeying Allah." (المجاهد من جاهد نفسه في سبيل اله) Imam At-Tirmidhi, Ahmad bin Hanbal, Tabarani and Ibn Majah.

${ }^{11}$ Reported by Imam At-Tirmidhi in his collection, on the authority of Abu Umamah al-Bahili.

$12 \mathrm{http}$ ://islamicsupremecouncil.org/understandin-islam.

${ }^{13}$ Qur'an, 2:194.

${ }^{14}$ Esposito, 223.

15 Badr al-Hassan al-Qasimi," al-jihad al-Islami wa sallam al-A 'lami," الجهاد الاسلامي و السلام العالميAl-

Ummah, Volum 5 no. 51, (14.5 H - 1985): 28.
} 
Jihad in its meaning is 'to struggle' as a general description. Jihad derives from the word juhd, which

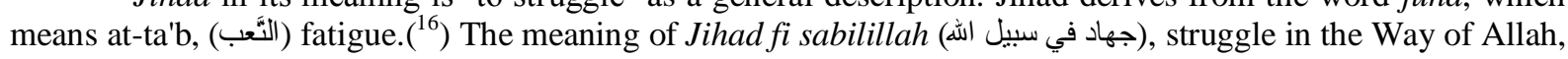
is striving to excess in fatiguing the self, to exhaust the self in seeking the Divine Presence and in bringing up

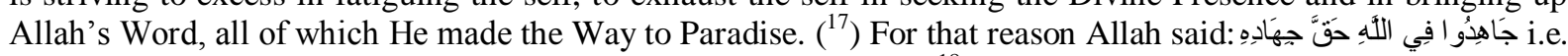
and strive in the cause of Allah as it behoves you to strive for it; $\left({ }^{18}\right)$ It is essential to understand that under the term ja'hiduu come many different categories of Jihad, each with its specific context. The common understanding of Jihad to mean only war is refuted by this tradition of the Prophet's: "A man asked the Prophet "Which jihad is best?" The Prophet said, "The most excellent Jihad is to say the word of truth in front of a tyrant." $\left({ }^{19}\right)$ In the fact, the Prophet mentioned this Jihad as "most excellent" means that there are many different forms of Jihad.

The most fundamental form of Jihad, usually overlooked in today's pursuit of newsworthy headlines, is the Jihad of presenting the message of Islam da'wah (الدعوة). Thirteen years of the Prophet's 23-year mission consisted purely of this type of Jihad. Contrary to popular belief, the word Jihad and related forms of its root word ja'hada are mentioned in many Meccan verses in a purely non-combative context. Combative Jihad in the technical usage of Islamic law means "the declaration of war against belligerent aggressors." It is not a haphazard decision taken by anybody but only by the leader of the nation. The principles of Islamic jurisprudence state that the actions of the leader must be guided by the interests of the people. $\left({ }^{20}\right)$

In firmness to the critics and in order to appreciate also position, it may be useful to quote those passage of the Qur'an from which the critics draw their wrong conclusions. The Qur'an says:

Permission (to take up arms) is given to those against whom war is made, because they have been wronged, and Allah, indeed, has the power to help them. - Those who have been driven out of their houses unjustly, only because they said "our Lord is Allah". And if Allah had no repelled some people by means of others, cloisters and Churches and Synagogues and Mosques, where in the name of Allah is often remembered, would surely have been destroyed. And Allah will, surely, help him who helps Him. $\left({ }^{21}\right)$

These verses show that the objectives of jihad as laid down in Islamic law do not provide that earth should be free from the followers of religions other than Islam. The main objective of jihad is defence against the tyrants by restraining the aggressor from continuing atrocities. $\left({ }^{22}\right)$ The reasons are enumerated here why Muslim were after all granted the permission to defend themselves. Firstly, they have been driven out of their homes, without any fault from their side. Secondly, they were not permitted to believe in God and to worship Him. Thirdly, so that the followers of all religion beliefs- Christian in their Churches and monasteries, Jews in their synagogues and Muslim in their Mosque- could enjoy the full liberty of conscience and belief and perform their religious service in peace and without let or hindrance. $\left({ }^{23}\right)$

In fact, the religious world ought to be grateful to Islam and early Muslims who so boldly and bravely stood for the protection of the inalienable right of man to the freedom of religion. We read in the Qur'an further: "And fight them (the transgressors) where ever you meet them and drive them out from where they have driven you out; for persecution is worse than killing... but if they fight, fight them." $\left.{ }^{24}\right)$

And fight them until there is no persecution, and religion is professed for Allah. But if they desist, then no hostility is allowed except against the wrongdoers. ${ }^{25}$ )

The teachings of Qur'an are clear-cut and unmistakable. The Qur'an speaks in sharp terms against every short of aggression and violence. It pleads for peace and harmony. It goes to the extent of saying that, if in the course of a war the enemy should desire truce, it became imperative for Muslims to stop all fighting, even though there may be a justifiable risk that the desire of peace on the part of the enemy is simply a deceiving manoeuvre and the enemy is seeking only to gain time by using this ploy. $\left({ }^{26}\right)$

\footnotetext{
${ }^{16}$ Al-Bustani, 105.

17 Abu Walid Muhammad bin Ahmad Ibn Rushdy: Al-Muqadima'at Al-Mumahida'at libaya'an maqtadhathu Al-Mudawanah minal hakam, (المقدمات الممهدات لبيان مااقتضته المدونة من الأحكام) (Cairo: Maktabah Al-thaqafatul diniyyah, 2004), 5/205

${ }^{18}$ Qur'an, 22:79

19 Abu Daud, At-Tirmidhi, and Ibn Majah, on the authority of Abu Sa'id al-Khudri.

${ }^{20} \mathrm{Abu}$ walid Muhammad bin Ahmad Bin Muhammad bin Ahmad Ibn Rushd (Al-Hafid): Bidayat AlMujahid Wanihayatul muqtasid, (Cairo: Darul-Fikr 1995), 1/311.

${ }^{21}$ Qur'an, 22:40- 41.

${ }^{22} \mathrm{http} / / /$ www.esyislam.com/jihad.asp (23/11/2012).

23 Ahmad, 22.

${ }^{24}$ Qur'a, 2:192.

${ }^{25}$ Qur'an, 2:194.

${ }^{26}$ Ahmad, 22.
} 
It is a mistake of the critics to regard these passages of the Qur'an as being applicable in normal times and to hastily infer that Islam wants Muslims to kill provided the world with a charter on peace and war. By using this charter, a war can be prevented and, if it does break out, its scope can be limited and it can be stopped quickly and its consequences can be mitigated.

In the second year after the Migration, Allah ordered the Muslims to fight by saying:

Fighting is ordained for you, though it is repugnant to you; but it may be that you dislike a thing while it is good for you, and it may be that you like a thing while it is bad for you. Allah knows and you know not. $\left({ }^{27}\right)$

This verse shows that in general warfare was disliked, not something sought after, but despite this, and it was called for at times when the security of the nation was threatened by external the belligerency. Therefore it is very cleared from the verse that Muslim hated war not because they were afraid of it, but because they did not like to shed human blood; also because they thought that a peaceful atmosphere was much more conducive to the spread and propagation of Islam than a state of war. $\left({ }^{28}\right)$ Thus, with a simple studious examination of the relevant verses, we discover then that there were two different kinds of Jihad: that of Mecca and that of Medina. The one in Mecca was primarily by education. In Medina Jihad was by two methods: by education, then by fighting after the enemies attacked the Muslim within their newly established state. Additionally, the Muslims who had been expelled invoked the right to return to their homeland, and if opposed to use force. $\left({ }^{29}\right)$ And this is just one of the jihads.

The combative Jihad was authorized only after the Prophet migrated along with his followers from Mecca to Medina, having been persecuted and finally expelled from their country running from persecution and torture. This is not unlike what we see today: people running from persecution in their home countries, becoming refugees in foreign nations. And the supporters, al-Ansa'r, (الأنصLار) of Medina, welcomed the refugees called al-Muhajirun, and shared with them all they possessed of their wealth and their homes. $\left({ }^{30}\right)$

\section{Jihad in its combative form}

The struggle in the way of Allah, Jihadun fi sabilillah, (جهاد في سبيل اله) when the Prophet began by teaching the Qur'an in his country, Mecca, was primarily one of enlightenment and education while in Medina his message became the basis for a model constitution for civic society and social life. This is borne out by the emphasis the Prophet made on caring for the poor, the emancipation of slaves, giving rights to women and building a civic society by levying taxes on the rich to benefit the poor, establishing community centers and community homes in which people could meet. These teachings were brought to a society in Mecca in which anarchy ruled and for this reason the Prophet was persecuted and fled to Medina. There he was able to establish a nation-state based on tolerance, freedom of speech and freedom of religion where all religions flourished together without conflict, coercion. $\left({ }^{31}\right)$ There should be no compulsion in the matter of faith, because faith cannot be imposed.

In establishing this society in Medina, the Prophet sought to keep his new nation safe, just as today every country has security as a dominant concern. Therefore he built up an army of his followers to keep his borders safe from any enemy attack. In particular they were under great threat due to the Prophet's teaching opposing the hegemony of tyrants. $\left({ }^{32}\right)$ Thus Medina became the first city for the believers in which the new message, Islam, was established and they sought to keep it safe. Just as all nations do today, they built up an army and weaponry. And, just as done in the modern world, if anyone attacks a nation, they are obliged to respond and repel those who attacked them. $\left({ }^{33}\right)$ So Jihad in its combative sense did not come about until after the Prophet and his Companions were forced to leave their country and hometown of Mecca, fleeing for safety to in Medina after thirteen years of propagating the call to the faith and calling for freedom of belief. It was on this fact that the majority of Muslims scholars including the four Sunni School of thought, Hanifite, Malikite, Safiite and Imam Ahmad ibn Hanbal say that combative Jihad is to defend oneself and to attack the aggressors. $\left({ }^{34}\right)$ Imam Malik bin Anas stated in المدونة الكبرىal-Mudawwanat-al-kubra:

${ }^{27}$ Qur'an,2 :217.

28 Farid, the Holy Qur'an, 2:88.

${ }^{29} \mathrm{http}$ ://islamicsupremecouncil.org/understandin-islam.

${ }^{30} \mathrm{Badr}, 28$.

${ }^{31} \mathrm{http}$ ://islamicsupremecouncil.org/understandin-islam.

${ }^{32} \mathrm{Badr}, 28$.

${ }^{33} \mathrm{http}$ ///islamicsupremecouncil.org/understandin-islam.

34 Burha'ndeen Ali bin Abi Bakr Al-Mirghnani: Al-Hidayyah, Sharih Bidayatul Mubtadi, (Beirut: Dar ihyai al-turath al-arabi, 1995), 1/379; Sidi Ahmad al-Dardir, Al-sharh al-saghir , (Cairo: Dar ihyai alKutub al-arabiyyah, 1982), 2/274; Abu Bakr bin Muhammad al-Husaini, Kifayatul Akhyar fi Ghyatil Ikhtisor, (Cairo: Dar ihyai al-Kutub al-arabiyyah, 1997), 205; Bahaudeen Abdulrahman bin Ibrahim AlMaqdasi, Al-uddah Sharh al-Umdah, (Cairo: Dar ihyai al-Kutub al-arabiyyah, 1997), 587. 
The first of what Allah has sent His Messenger is to call people to Islam without fighting. He didn't give him permission to fight nor to take money from people. The Prophet stayed like that for thirteen years in Mecca, bearing all kinds of persecutions, until he left for Media. $\left({ }^{35}\right)$

Imam Nawawi in his book al-Minhaj, when defining Jihad and its different categories, said:

One of the collective duties of the community as a whole (fard kifäyah) is to lodge a valid protest, to solve problems of religion, to have knowledge of Divine Law, to command what is right and forbid wrong conduct. $\left({ }^{36}\right)$

Similarly, Imam Bahuti commences the chapter on Jihad in his book Kashf al-qina'a by showing the injunctions of collective religious duties (kifayah) that the Muslim Nation must achieve before embarking on combative Jihad, including preaching and education about the religion of Islam, dismissing all the uncertainties about this religion and making available all the skills and qualifications which people might need in their religious, secular, physical and financial interests because these constitute the regulations of both this life and the life to come. $\left({ }^{37}\right)$ Hence, da'wah performing the activities of propagating Islam and its related fields of knowledge-is the cornerstone of the 'building' of Jihad and its rules; and any attempt to build without this 'stone' would damage the meaning and reality of Jihad.

\section{Rules of Combative Jihad}

In the time of the Prophet he was leader, so this applied to anything directed from himself to the Muslims. After the Prophet, such directives became the responsibility of the caliph, his successor. This means the Imam of the Muslims is the leader of every Muslim nation. He is the person responsible for the application of the rules as he sees fit. These rules are flexible within the geographical, societal and cultural norms of the nation, which the leader can exercise by Allah's grace, to apply them for the benefit of all the people. $\left({ }^{38}\right)$ Thus, declaring combative Jihad is the topmost responsibility of the Imam (leader, president or king of a nation). He is the only responsible body that can declare the time and place of Jihad lead it or terminate its mission. ${ }^{39}$ ) We may quote in support of this few the authority from the respected scholars of the four Sunni Schools of Islamic jurisprudence. Referring to the pre-requisite of state authority, the Prophet said:

A Muslim ruler is the shield (of his people). A war can only be waged under him and people should seek his shelter (in war). In another translated version, the imam is armour for protection, the battle is fought for his protection and through him protection is sought. $\left({ }^{40}\right)$

The ruler, the Imam, is completely answerable to the people and their legal apparatus, the most important representatives of whom are the scholars. The position of the Islamic law is that only at such a time when it can be reasonably proven that; there are aggressive designs against Islam; and, that there are concerted efforts to eject Muslims from their legally acquired property; and, that military campaigns are being launched to eradicate them. At such a time the ruler can declare and execute the provisions of combative Jihad. The Rules of Leadership are those rules that have been directed from the leader to the citizens. $\left.{ }^{41}\right)$

Al-Sarkhasī in al-Mabsūț said: "The Ruler of the Muslims must almost always exert all efforts to lead an army himself or dispatch a military detachment of Muslims; and trust in Allah to aid him in achieving victory." ( $\left.{ }^{42}\right)$ Al-Dardir says: "proclaiming Jihad comes through the Ruler's assignment of a commander." $\left({ }^{43}\right)$ Mawardī, a Shafi'ite authority, while enumerating the obligations of a Muslim ruler says: "His sixth obligation is

\footnotetext{
35 Malik bin Anas, المدونة الكبرى al-Mudawwanat al-kubra, (Cairo: Maktabah Al-thaqa'fatul diniyyah, 2004), 1/543.

${ }^{36}$ Abu Zakariyya Yahya bin Sharaf An-Nawawi: al-Minhaj, (Cairo: Matbaah Musfafa Al-Babi Al-Halabi, 1956), $2 / 248$.

${ }^{37}$ Monsur bin Yunes al-Bahuouti: Kasf al-kina'a, (Mecca: Matbaah al-Hukumah,1980), 2/278

${ }^{38} \mathrm{http}: / /$ islamicsupremecouncil.org/understandin-islam.

${ }^{39} \mathrm{http}: / /$ islamicsupremecouncil.org/understandin-islam.

${ }^{40}$ Ali, "the Manual", 397.

${ }^{41} \mathrm{http}: / /$ islamicsupremecouncil.org/understandin-islam.

${ }^{42}$ Shms al-A'mmah Abu Bakr Muhammad ibn Abi Sahl Al-Sarakhsi, Al-Mabsut, (Beirut: Dar Al-

Ma'rifah, 1968), 10/99.

${ }^{43}$ Al-Dardir, 2/274.
} 
to conduct combative Jihād against those who show hostility against Islam..." $\left({ }^{44}\right)$ in support of the same few Ash-Sharbini said:

Collective-duty Jihad becomes applicable when the Imam fortifies the frontiers (to gain equal military parity with the enemy), reinforces the fortresses and ditches, and arms his military leaders. It also becomes relevant by the Imam or his deputy's leading the army... ${ }^{45}$ )

In al-Mughni, Ibn Qudama, a respected scholar of the Hanbali School, states: "Declaring Jihad is the responsibility of the Ruler and is his independent legal judgment. And it is the duty of the citizens to obey whatever he regards appropriate." $\left({ }^{46}\right)$

The Pakistani monthly Renaissance, in discussing the authorization for declaring combative Jihad says: Both the Qur'an and the established practice of the prophets of Allah explicitly say that Jihad can only be waged by a state. No group of people have been given the authority to take up arms, because individual groups if given this license will create great disorder and destruction by fighting among themselves once they overcome the enemy. A study of the Qur'an reveals that the Mecca revealed chapters do not contain any directive of combative Jihad for the fundamental reason that in Mecca the Muslims did not have their own state. $\left({ }^{47}\right)$

Islam does not advocate "the law of the jungle." It is a religion in which both human life and the way it is taken hold utter sanctity. Thus Islam does not give Muslims any right to take life unless certain conditions are fulfilled. Sayyid Sābiq, while referring to this consensus, writes: "Among kifayah obligations, there is a category for which the existence of a ruler is necessary e.g., combative Jihad and administration of punishments. " ${ }^{48}$ )

This condition is so explicit and categorical that all the scholars of the past and contemporary unanimously uphold it. Zafar Aћmad 'Uthmani, a Hanafite jurist writes:

It is obvious from the Hadith narrated by Makhul that Jihad becomes obligatory with the ruler who is a Muslim and whose political authority has been established either through nomination by the previous ruler similar to how Abu Bakr transferred the reins [of his Khilafah to 'Umar or through pledging of allegiance by the 'ulama or a group of the elite ...in my opinion, if the oath of allegiance is pledged by 'ulama or by a group of the elite to a person who is not able to guard the frontiers and defend honour of the people organize armies or implement his directives by political force neither is he able to provide justice to the oppressed by exercising force and power, then such a person cannot be called 'Amir' (leader) or 'Imam' (ruler). He, at best, is an arbitrator and the oath of allegiance is at best of the nature of arbitration and it is not at all proper to call him 'Amir' (leader) or an 'Imam' (ruler) in any [official] documents nor should the people address him by these designations. ...It is not imperative for the citizens to pledge allegiance to him or obey his directives and no combative Jihad can be waged alongside him. $\left({ }^{49}\right)$

In the words of Imam Farahi:

In one's own country, without migrating to an independent piece of land, [combative] Jihad is not allowed. The tale of Abraham and other verses pertaining to migration testify to this. The Prophet's life also supports this view. The reason for this is that if combative Jihad is not waged by a person who holds political authority, it amounts to anarchy and disorder.

The Salafi scholar Al-Albani, stressing the necessity of Jihad being established by the ruler of the Muslims said: "In the present time there is no Jihad in the Islamic land, while undoubtedly there is combat taking place in numerous places but there is no Jihad, established under a solely Islamic banner that abides by Islamic legislation." ${ }^{50}$ )

From this we can understand that it is not permitted for a soldier to act according to his own wishes, but he is obliged to follow the rules of the commander and his commands and that commander who was delegated with proper authority by the Caliphate of Muslims. So we can ask ourselves today, "Where is the accepted Caliphate of Muslims in the present time?" Since there is no accepted caliphate, the fundamental principle of leadership is no longer present. So while there still remains combat between one nation and another it is no longer considered as fulfilling the religious obligation that Jihad entails. $\left.{ }^{51}\right)$

${ }^{44}$ Abu'l Hassan Ali ibn Muhammad: Al-Mawardi, al-ahkam as-Sultaniyya, (the Laws of Islamic Governance), (London: Ta-Ha Publishers Ltd, 1996), 48.

${ }^{45}$ Muhammad Al-Khatib Ash-Sharbini: Mughni Al-Muhtaj, (Cairo:Al-Maktabah Al-tujariyyah Al-Kubrah, 1980), $2 / 10$

${ }^{46}$ Abdullah bin Ahmad bin Muhammad ibn Qudama: Al-Mughni, (Beirut: Dar Al-Kitab Al-arabi, 1972), 9/184.

${ }^{47} \mathrm{http}: / /$ islamicsupremecouncil.org/understandin-islam.

${ }^{48} \mathrm{http}: / /$ islamicsupremecouncil.org/understandin-islam.

${ }^{49} \mathrm{http}: / /$ islamicsupremecouncil.org/understandin-islam.

${ }^{50} \mathrm{http}: / /$ islamicsupremecouncil.org/understandin-islam.

${ }^{51} \mathrm{http}: / /$ islamicsupremecouncil.org/understandin-islam. 
These represent only a sampling of many quotes from scholars regarding the combative Jihad demonstrate the responsibility of the Imamate in ordering it. The Imam (Ruler) in fact, is the only one responsible in repelling aggressors and to see what actions are fitting for the country. The actual title whether he be called Imam, caliph, king or president, is not important - his position as ruler is what counts. The leader is the one who has been elected to administer the foreign policy of his nation, and he has been entrusted by the people to conduct the common affairs of the state, sign treaties, forbid wrong deeds, suppress criminals, fight aggressors, and settle people down in their homes and the like. $\left({ }^{52}\right)$

This specific duty can never devolve to a group of people living in a country who come against a government by terrifying innocent citizens. It is not acceptable in Islam by any means for someone to declare combative war if he is not in the position of leadership. The many aforementioned rulings of scholars and the many verses of Qur'ān and hadith citation expose the methods of the so-called "Islamic parties"' who establish states within the state and act as if they are the rightful rulers of Muslims. Their methodology is to initiate war by attacking non-Muslims in their country or other countries, and they do this without the permission of the Muslim rulers or the Muslim nation and without the consensus of its scholars. What happens then? The result is that everyone suffers from the disastrous consequences of their actions. $\left({ }^{53}\right)$

It is in no way the responsibility of individual Muslims to declare Jihad without the order of the leader. It must be noted also that the Ulama (عاء) the learned or Muslim scholars are not in a position to issue a call for combative jihad. Jihad is not terrorism, it is to be emphasized that terrorism against the innocent civilians, whether through aggression or suicidal means, is under no circumstances permissible in Islam. Terrorism is not Jihad; it is Fasad (mischief). It is against the teaching of Islam. Allah said: "When it is said to them: Create not disorder in the earth, they say, we are only promoters of peace. Beware! It is surely they who create disorder, but they do not perceive it." $\left(^{54}\right)$ Islam does not advocate "the law of the jungle." It is a religion in which both human life and the way it is taken hold utter sanctity. Thus Islam does not give Muslims any right to take life unless certain conditions are fulfilled.

\section{Combative Jihad and wars of self-interest}

In olden days when the Muslim universities were at the height of their power and influence, the learned in the sacred Law judged independently, distinguished clearly between Jihad warfare and wars of mere ambition or self-interest. It is unanimously and invariably condemned the latter as totally un-sanctioned by the shariah. Wars which fall under the heading of Jihad can be fought only in self-defense, for the protection of the weak that are oppressed, and the redress of the wrong. The prophet said: "he who fights or dies, motivated by prejudice is not one among us." ${ }^{55}$ ) Non combatants must not be harmed, priest and religious institutions have to be respected, and crops must not be curt down. "Destroy not their means of subsistence." That was the prophet's law against his enemies. The prophet in his warfare several times forgave his enemies, with wonderful results. There is no command in the Qur'an or the Sunnah of the prophet to murder and massacre. $\left({ }^{56}\right)$ There is not one word in the Holy Quran to justify murder or massacre under any circumstances whatsoever. Therefore all of the Muslim community all over the world are and should condemn the brutality of the Muslim militant anywhere in the world. Dispassionately, the study of the Qur'an shows that it is fable against Islam that it preaches violence and the use of force and is not an advocate of complete freedom of religion. One, who claims the contrary, is to be pitied for his ignorance. Terrible and ghastly things are happening in certain countries of the world, unfortunately, in the name of Islam. None of these horrible happenings has the power to change our conviction that Islam is the religion of peace which has declared the life and the conscience of every person as something inviolable and sacrosanct. Thus Islam should be judged on the basis of its teachings and not necessarily on the basis of the conduct of some of its followers.

\section{Conclusion}

It is apparent that the understanding of Jihad as a concept is dismally blurred by the ongoing rhetoric employed by financially-empowered Islamist activists and extremist scholars. Disregarding centuries of classical scholarship, using a simplistic, literal approach to the Qur'an and holy traditions of the Prophet, they have built a convincing picture of Jihad as militant, continuing warfare between the Muslims and non-Muslims; a situation they contend will maintain until the end of time. The only way to dispel the false notions of Jihad put forth by the extremists, who are massively funded by external sources, is an equally strong effort put forth by Muslim governments in re-education of their populations, in particular the youth, with a correct understanding of this

\footnotetext{
${ }^{52} \mathrm{http}: / /$ islamicsupremecouncil.org/understandin-islam.

${ }^{53} \mathrm{http}: / /$ islamicsupremecouncil.org/understandin-islam.

${ }^{54}$ Qur'an, 2:12-13.

${ }^{55}$ Abu Daud Kitab-ul-Jihad.

${ }^{56} \mathrm{Al}$-Shawkani, 7/230
} 
term. Such efforts must be sustained and ongoing and must have the support of modern, moderate Muslim scholars in each nation. If we are to tackle this problem, there must be a sincere and honest political will. This can only be achieved by encouraging the moderate independent scholars to stand up and speak up in opposition to the extremists, through paper presentations at conferences and seminars. In the modern society where all are living in global village, where non-Muslims and Muslims are living together, it is their moral and national duty to have better understanding among themselves, work for peace and justice for all people. They should cooperate with each other in matters of goodness and virtue in order to stop all terrorism, aggression and violation against the innocent people. This is the holy Jihad that must be fought collectively today. 